Uveitis Update 


\section{Developments in Ophthalmology}

Vol. 31 


\section{Uveitis Update}

Volume Editor D. BenEzra, Jerusalem

53 figures, 2 in color and 16 tables, 1999

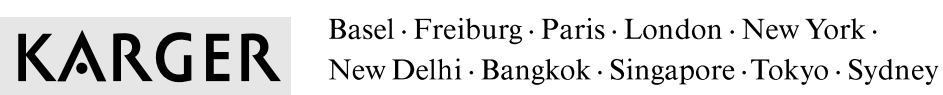




\section{BenEzra, MD, PhD}

Department of Ophthalmology

Hadassah University Hospital

P.O. Box 12000

Jerusalem 91120 (Israel)

Continuation of 'Bibliotheca Ophthalmologica', 'Advances in Ophthalmology', and

'Modern Problems in Ophthalmology'

Founded 1926 as 'Abhandlungen aus der Augenheilkunde und ihren Grenzgebieten' by

C. Behr, Hamburg and J. Meller, Wien

Former Editors: A. Brückner, Basel (1938-1959); H.J.M. Wewe, Utrecht (1938-1962);

H. M. Dekking, Groningen (1954-1966); E. B. Streiff, Lausanne (1954-1979);

J. François, Gand (1959-1979; J. van Doaesschate, Utrecht (1967-1971);

M.J. Roper-Hall, Birmingham (1966-1980); H. Sautter, Hamburg (1966-1980);

W. Straub, Marburg a.d. Lahn (1981-1993)

Library of Congress Cataloging-in-Publication Data

Uveitis update / volume editor, D. BenEzra.

(Developments in ophthalmology; vol. 31)

Includes bibliographical references and index.

1. Uveitis. I. BenEzra, David. II. Series.

[DNLM: 1. Uveitis. W1 DE998NG v.31 1999]

RE351.U94 1999

$617.7^{\prime} 2-\mathrm{dc} 21$

ISSN $0250-3751$

ISBN 3-8055-6891-6 (hardcover: alk. paper)

Bibliographic Indices. This publication is listed in bibliographic services, including Current Contents ${ }^{\circledR}$ and Index Medicus.

Drug Dosage. The authors and the publisher have exerted every effort to ensure that drug selection and dosage set forth in this text are in accord with current recommendations and practice at the time of publication. However, in view of ongoing research, changes in government regulations, and the constant flow of information relating to drug therapy and drug reactions, the reader is urged to check the package insert for each drug for any change in indications and dosage and for added warnings and precautions. This is particularly important when the recommended agent is a new and/or infrequently employed drug.

All rights reserved. No part of this publication may be translated into other languages, reproduced or utilized in any form or by any means electronic or mechanical, including photocopying, recording, microcopying, or by any information storage and retrieval system, without permission in writing from the publisher.

(C) Copyright 1999 by S. Karger AG, P.O. Box, CH-4009 Basel (Switzerland)

www.karger.com

Printed in Switzerland on acid-free paper by Reinhardt Druck, Basel

ISBN 3-8055-6891-6 


\section{Contents}

VII Preface

1 Newer Methodologies in Immunohistochemistry and Diagnosis Chan, C.-C.; Shen, D.F. (Bethesda, Md.)

14 Ultrasound and Ultrasound Biomicroscopy as a Diagnostic Tool Deschênes, J.; Mansour, M.; Rudzinski, M. (Montreal)

22 Lessons to Be Learned from Experimental Uveitis Rizzo, L.V.; Valochi, A.L. (São Paulo)

31 Lymphocyte Surface Antigens in Uveitis Patients Proença, R.; Mota Pinto, A.; Santos Rosa, M. (Coimbra)

53 The Role of Cytokines and Chemokines in Uveitis Wakefield, D.; Cuello, C.; Di Girolamo, N.; Lloyd, A. (Sydney)

67 Oral Tolerance in Autoimmune Uveitis Wildner, G.; Thurau, S.R. (Munich)

77 Immunogenetics and Uveitis Yabuki, K. (Yokohama); Inoko, H. (Isehara); Ohno, S. (Yokohama)

92 Essential Laboratory Tests in Uveitis Becker, M.D.; Rosenbaum, J.T. (Portland, Oreg.)

109 Clinical Aspects and Diagnostic Guidelines of Ocular Behçet's Disease BenEzra, D. (Jerusalem)

118 Medical Management of Behçet's Syndrome Yazici, H.; Ozyazgan, Y. (Istanbul) 
132 The Use of Immunosuppressive Drugs in Uveitis Carnaham, M.C.; Goldstein, D.A. (Chicago, Ill.)

160 Prediction of Treatment Outcome in Uveitis BenEzra, D.; Cohen, E.; Maftzir, G. (Jerusalem)

166 Surgery of Cataract in Patients with Uveitis Alió, J.L.; Chipont, E. (Alicante)

175 Postsurgery Intraocular Inflammation Schmitz, K.; Behrens-Baumann, W. (Magdeburg)

192 Management of Ocular Manifestations in Patients with Acquired Immunodeficiency Syndrome

Pivetti-Pezzi, P.; Accorinti, M. (Roma)

210 Author Index

211 Subject Index 


\section{............................. \\ Preface}

To prepare an update on any medical and/or scientific subject today is an arduous task. Restrictions forced on the authors regarding the length of their contribution, the number of clinical photographs and the necessity to conform to a tight deadline make the writing and editing of an update on a subject like 'uveitis' a challenging goal. Once I had accepted Prof. BehrensBaumann's request to serve as the editor of this volume, the first task was to identify the most pertinent subject in uveitis needing to be updated. It was immediately obvious that the most suitable solution would be to have half of the chapters devoted to basic sciences and half of them devoted to clinical subjects.

I was fortunate to have succeeded in persuading Dr. Chan to be responsible for 'Newer Methodologies in Immunohistochemistry and Diagnosis', Dr. Deschênes 'Ultrasound and Ultrasound Biomicroscopy as a Diagnostic Tool', Dr. Rizzo 'Lessons to Be Learned from Experimental Uveitis' and Dr. Proença 'Lymphocyte Surface Antigens in Uveitis Patients'. I am particularly indebted to Dr. Wakefield for the writing of 'The Role of Cytokines and Chemokines in Uveitis'. The cooperation between Dr. Wildner and Dr. Thurau yielded 'Oral Tolerance in Autoimmune Uveitis'; Dr. Ohno and his group are authoring 'Immunogenetics and Uveitis', while Dr. Rosenbaum was responsible for 'Essential Laboratory Tests in Uveitis'. Dr. Yazici, one of the most renowned experts on the rheumatological manifestations of Behçet's disease, undertook the writing for 'Medical Management of Behçet's Syndrome' and Dr. Goldstein was responsible for 'The Use of Immunosuppressive Drugs in Uveitis'. Dr. Alió, who is the principal investigator of the multinational-multicenter study Surgery of the Cataract in Uveitis conducted under the auspices of the International Ocular Inflammation Society, agreed to be responsible for 'Surgery of Cataract in Patients with Uveitis', while Dr. Behrens-Baumann and Dr. Schmitz wrote 'Postsurgery Intraocular Inflammation'. To my mind, 
there was no one better than Dr. Pivetti-Pezzi to be responsible for 'Management of Ocular Manifestations in Patients with Acquired Immunodeficiency Syndrome'. This closing chapter of the Update illustrates best both the tremendous progress made in the management of AIDS and our present understanding of the processes associated with intraocular inflammatory reactions in patients suffering from this ailment. I have taken responsibility for 'Clinical Aspects and Diagnostic Guidelines for Ocular Behçet's Disease' and 'Prediction of Treatment Outcome in Uveitis' to stimulate some thoughts about newer avenues in designing the future medical management of intraocular noninfectious inflammatory diseases (uveitis).

I am grateful to my colleagues who enthusiastically helped me in this endeavor, devoting their time and efforts and contributing to the realization of this timely update volume on uveitis. We all are expecting that this update will be of help to the ophthalmic clinicians and scientists as well as to the internists and immunologists.

Last but not least, I am indebted to Mrs. Margaret Kuttner for her invaluable help in editing this volume.

David BenEzra, Jerusalem 